\title{
Multidimensional Assessment of Job Satisfaction in Telework Conditions. Case Study: Romania in the COVID-19 Pandemic
}

\author{
Monica Aureliana Petcu $(\mathbb{D}$, Maria Iulia Sobolevschi-David, Adrian Anica-Popa $\mathbb{(}$, Stefania Cristina Curea *(D), \\ Catalina Motofei (D) and Ana-Maria Popescu (D)
}

check for

updates

Citation: Petcu, M.A.;

Sobolevschi-David, M.I.; Anica-Popa,

A.; Curea, S.C.; Motofei, C.; Popescu,

A.-M. Multidimensional Assessment

of Job Satisfaction in Telework

Conditions. Case Study: Romania in the COVID-19 Pandemic.

Sustainability 2021, 13, 8965. https://

doi.org/10.3390/su13168965

Academic Editors: Magnus Moglia and John Hopkins

Received: 7 July 2021

Accepted: 3 August 2021

Published: 11 August 2021

Publisher's Note: MDPI stays neutral with regard to jurisdictional claims in published maps and institutional affiliations.

Copyright: (c) 2021 by the authors. Licensee MDPI, Basel, Switzerland. This article is an open access article distributed under the terms and conditions of the Creative Commons Attribution (CC BY) license (https:// creativecommons.org/licenses/by/ $4.0 /)$.
Department of Financial and Economic Analysis and Valuation, Bucharest University of Economic Studies, 010374 Bucharest, Romania; monica.petcu@cig.ase.ro (M.A.P.); maria.sobolevschi@cig.ase.ro (M.I.S.-D.); adrian.anica@cig.ase.ro (A.A.-P.); catalina.motofei@cig.ase.ro (C.M.); ana.fundulea@cig.ase.ro (A.-M.P.)

* Correspondence: stefania.curea@ase.ro

\begin{abstract}
Improving employee performance is one of the main levers for companies to achieve their goals. The detachment of work from place is a growing trend, affecting the performance levels of both employees and employers. The purpose of this research was to assess job satisfaction in telework conditions, based on areas considered decisive and evaluated by specific items. To this end, an opinion questionnaire was created, the information was processed with correlation analysis and regression analysis. This study showed that job satisfaction in telework is associated with higher skills, autonomy, and a favorable organizational climate, but also with a higher level of emotional exhaustion generated by constant access to work, as well as the lack of relationships and mentoring. We found a statistically significant positive link between competencies, autonomy, organizational climate, and job satisfaction. Significant differences were observed in the perception of job satisfaction with respect to the gender dimension, as well as between employees of various age categories.
\end{abstract}

Keywords: telework; job satisfaction; competencies; autonomy; emotional exhaustion; organizational climate; SDGs

\section{Introduction}

Society is undergoing a period of major changes imposed by the need to increase syntropia in all its systems and subsystems and to correct the synergy of errors in decisionmaking processes that have profoundly affected the state of the whole. The accelerated development of the digital economy has opened new approaches to productive processes from higher levels, introducing technologies with possibilities for improvement and progress and creating the conditions for a major restructuring of the entire socioeconomic ensemble. Uploading a huge volume of information on large platforms ensures free access to it and ensures the improvement and cognitive development of any individual. This technology also contributes to the expansion of globalization and the functioning of multinational companies with a common decision-making core for many subdivisions with widely dispersed geographic locations. IT facilities allow the remote performance of many operations related to the functions of the enterprise that can be realized at low cost, subject to the existence of reliable and secure systems for the circulation of information.

The pandemic generated by the SARS-CoV-2 virus required many employers from public and private systems to resort to telework as a viable possibility for employees to continue working in compliance with the restrictions adopted and as a safety measure. According to the European Commission [1], telework involves: the existence of an employment contract; work in whole or in part outside the employer or client workplace, at the employee's home, or in the form of mobile work; use of information technology; communication with the organization. The transition to telework is a significant change in the activity of employees and involves ensuring adequate organizational conditions. 
In assessing the well-being of the individual, satisfaction is a defining dimension. Satisfaction is a subjective state related to the aspirations and expectation level of the individual with a strong adaptive character, depending on their opportunities, conditions, and own abilities. Satisfaction is directly conditioned by the competencies developed and is measured by the congruence between capabilities, aspirations, and reality. The complexity of this concept requires approaching it as a composite area. Regarding job satisfaction, people develop competencies appropriate to maximizing the satisfaction from carrying out an activity in terms of both income and their own development, self-realization, and performance. The evaluation of job satisfaction in telework conditions can be carried out from the perspective of social exchange theory [2]. The shared expectations of employees and employers, based on the reciprocity of their involvement and commitment, can be achieved by promotion of telework on an extended scale. Most studies show that telework has a positive relationship with job satisfaction [3-8]. On the other hand, recent studies have indicated that during the COVID-19 pandemic, "employees felt more stressed and in conflict at their remote workstations when they had to telework, and this negative output was significantly related to the deterioration of working dimensions like space, quality, and design" [9].

The literature states that among the advantages of this work regime are a work-life balance, increase in autonomy, professional development, reduction of medical absences, and more opportunities for family life. Among the main disadvantages are the intensification of work, difficulties in detaching from problems at home, concerns about extending work tasks beyond normal working hours, and, finally, exhaustion. There is also a positive correlation between telework and performance $[7,10,11]$.

The increased concern about sustainable development materialized in the adoption of the 2030 Development Agenda by all member states of the United Nations, which includes 17 sustainable development goals (SDGs) and 169 targets. This assumes responsibility for a more inclusive, equitable, prosperous, and sustainable future, in an approach that includes social, economic, and environmental dimensions [12]. In this study, we considered the relevant SDG8: Promote sustained, inclusive, and sustainable economic growth, full and productive employment, and decent work for all; SDG5: Achieve gender equality and empower all women and girls; and SDG10: Reduce inequality.

The dynamism and complexity of the environment as a result of both technological developments and changes in the general perception of well-being require appropriate changes in organizational configurations, labor relations, individual expectations, and new perspectives circumscribed by social exchange theory. Existing studies have not integrated approaches to job satisfaction evaluation in holistic systems, particularly in telework. There is also a lack of job satisfaction approaches in terms of implementing SDG5, SDG8, and SDG10. This study aims to fill these gaps. The purpose of this article is to propose a multidimensional model for evaluating job satisfaction. To this end, the relationship between competencies, autonomy, emotional exhaustion, organizational climate, and job satisfaction is investigated and tested under the conditions of telework expansion because of the crisis generated by SARS-CoV-2 virus. The purpose of this article is to develop the tools used in assessing job satisfaction, by deepening the analysis factors, contextualizing the work regime, and identifying the specific aspects regarding the differences in perception of job satisfaction (according to gender and age and the impact of creating decent working conditions). The following research questions are considered: RQ1: Is there a statistically significant link between competencies, autonomy, emotional exhaustion, organizational climate, and job satisfaction in the case of teleworking? RQ2: Are there any differences in terms of job satisfaction between the genders and by age categories for telework employees? The following sections aim to review the literature, presenting the dimensions considered decisive in evaluating job satisfaction, research methodology, empirical study results, and discussion, as well as the future research conclusions and directions. 


\section{Literature Review}

Assessing job satisfaction is a topic of interest in academia and for managers and HR specialists, considering the impact on employee motivation and implicitly on labor productivity and company performance. The difficulty measuring complex social phenomena is explained by "implicit conception of causality, the policy of correlation without explanation" [13]. Inspection of the literature reveals a constant focus on defining job satisfaction as a result of awareness of the importance of an individual as an asset, and as an innovative, creative, generating performance factor. Consequently, there is increasing interest in publishing on this topic, from 35,900 articles in 1969 to 3,010,000 articles in 2021, as identified on the academic platform Google Scholar, consulted in July 2021, using "job satisfaction" as a keyword.

Defined as an emotional-affective response to a job or job-specific aspects [13], job satisfaction can be assessed by positive or negative feelings about work. Therefore, it reveals the degree to which people like or dislike their work [14-16]. In addition, the cognitive job satisfaction is also addressed, being evaluated through conditions, opportunities or outcomes [17], remuneration, opportunities, or many other discriminatory jobs [13], and considering that "a cognitive judgment entails relating an existent to a cognitive (nonevaluative) standard" [13]. According to the expectancy theory [18], behavior is affected by preferences for certain outcomes, as well as the degree to which these outcomes are considered possible. From the perspective of this approach, job satisfaction can be assessed in terms of the expectations that exist for that job. Such expectations are determined by the probability that the performance of a job can lead to certain results (salary, working conditions, promotion, etc.), with different values depending on the perception of the degree of realization. According to the theory of goals developed by Latham and Locke [19], motivation and performance are higher when individuals set specific (difficult, but accepted) goals, which implies the existence of appropriate feedback in terms of performance. Assessing job satisfaction from this perspective involves setting certain levels of performance in order to motivate oneself, as well as an evaluating system in order to implement the best decisions necessary to achieve them. Job satisfaction can be addressed by including the theory of equity in reasoning, the fairness with which people feel rewarded based on their contribution and comparing to the others [20].

Changing paradigms on well-being requires the development of approaches to job attitudes: humanist perspectives, which implies affective approaches based on the evaluation of subjective and internal factors; calculative models, based on rationality assumptions and on attitude formation according to the objectively observed working conditions; content perspectives that take into account the importance of job and organizational features as predictors of job attitudes; and dispositional perspectives according to which job attitudes depend on personal characteristics, regardless of external conditions [21].

In a job satisfaction survey, many subscale measures of employee job satisfaction (as a combined score of some specific items) have been proposed: satisfaction with supervision, coworkers, pay, promotional opportunities, and the work itself-Job Descriptive Index [22]; pay, promotional opportunities, supervision, benefits, contingent rewards, operating procedures, co-workers, nature of work, communication [23]; the job itself, fellow workers, supervision, sales training and home office support, top management and the company, company salaries and benefits, promotion/advancement, and customers [24]; physical and mental exertion, relations with associates, relations with employer, security, advancement and finances, interest in, liking for, and emotional involvement in the job, job information and status, physical environment and working conditions, future, goals, and progress toward goals, and evaluation [25]. The persistence of certain items and aspects corresponding to the evolution of the economic and social environment is noted in the measurement of overall satisfaction.

A topic in research is the relationship between a high-performance work system (HPWS, involving three concepts: performance, work practices, and systemic effects [26]) and job satisfaction, with literature data finding a positive and significant correlation 
between them [27-29]. The HPWS implementation creates an environment that provides the employees a higher involvement, participation in decision making, motivation, desire to improve knowledge, skills, and responsibility, with an increase in job satisfaction and ensuring a competitive advantage to the company. Demographic variables, job rank, and nature of tenure [30], as well as the organizational identification [31], moderate the relationship between perception of the existence of the HPWS and job satisfaction.

Telework is a flexible way of working that allows employees to carry out their activities in different locations using ICTs. Telework is often adopted voluntarily, due to its advantages for companies (saving office space, increasing productivity, less absenteeism, flexibility of labor relations), for employees (flexibility, autonomy, personal freedom, cost savings, opportunities for people with disabilities), and for traffic management (by reducing work-related travel and avoiding rush hour travel) [32,33]. During the pandemic, telework was a mandatory form of activity due to mobility restrictions imposed by governments and for reasons of staff safety.

Adapting the management model in a pandemic environment aims to manage business continuity or organizational resilience [34]. There are debates in the literature about the degree of heterogeneity of the resilience of each organization. Approaching resilience from the dynamic capabilities and resource-based perspectives shows that it differs for each company or industry, being inherent in an organization and dependent on its resources and capabilities [35]. In this context, dynamism and flexibility are key features of human resource management, which must promote win-win approaches. One of the effects of the COVID-19 pandemic in the workplace has been the spread of telework, which ensures a higher degree of job satisfaction among employees. This has led to the maintenance of teleworking even after the lifting of restrictions, and not just as an occasional measure derived from environmental or health catastrophes [5,36,37].

Studies on the evaluation of job satisfaction in the conditions of telework reveal multiple aspects. The position, the training obtained from the company, the relationship with supervisors, and the environmental conditions at work have a strong relationship with job satisfaction, while a weak relationship implies job stability, security, opportunities of promotion, and growth [38]. Teleworking ensures a better satisfaction of the psychological needs for autonomy, competence, and relationships [39]. Conversely, teleworkers with a low intensity of teleworking are more vulnerable to technostress [40]. Furthermore, comparative studies on job satisfaction between teleworkers and office-based employees show that high-intensity teleworkers are more satisfied, especially as a result of the decline of the work-life conflict [4].

Research has shown that autonomy is an important component for job satisfaction of employees in various activities [41-47]. Keenan defines autonomy through five attributes: independence, capacity for decision making, judgment, knowledge, and selfdetermination [48]. It was also observed that job autonomy moderates the relationship between job satisfaction and performance [49]. Similar to general telework in normal times, it has been found that employees who are more dependent on co-workers faced difficulties in telework during the COVID-19 crisis. At the same time, employees who have high work autonomy may also have a lower satisfaction, receiving a lot of feedback, due to the difficulties in keeping a work-life balance, and due to working in a space with multiple destinations [50]. In addition, competencies positively affect job satisfaction [51-55]. General competencies, represented by "intelligence, information-processing models, key competencies, and meta-competencies" [56], have a statistically positive relationship with job satisfaction [56], while business competences have effects of differing intensities on job satisfaction [57]. Emotional exhaustion is related to job satisfaction, having contradictory results regarding its evolution [58-61]. "Work engagement and psychological detachment from work during off-job time predict high positive affect and low negative affect and that psychological detachment is particularly important when work engagement is high" [62]. In terms of workplace stress, effectiveness (and not gender) is a strong predictor. The degree to which employees are confident in their skills and abilities to cope with problems 
influences job satisfaction [63]. Emotional exhaustion was higher for the employees in telework during the lockdown [9]. Studies in the field show a strong positive correlation between the organizational climate and job satisfaction [64-66]. Employees' likelihood of leaving work decreases as job satisfaction increases. Ensuring working conditions that stimulate the employee to achieve relevant individual work-related values diminishes staff mobility, with effects on job performance [67]. From a gender perspective, "women have a more positive view on telework thanks to the COVID-19 crisis and indicate the strongest desire to perform more telework in the future" [50].

The analysis of the correlations between the work motivation factors (such as organizational commitment, job involvement, job satisfaction, and work characteristics) reveals a significant interrelation, with identification of positive relationships between motivations and characteristics, as well as between motivational factors, in which job involvement has a mediating role [68].

\section{Defining Domains}

This approach proposes an analysis of job satisfaction, by assessing four areas: competencies, autonomy, organizational climate, and emotional exhaustion, with all this appreciated on the basis of specific items (Figure 1):

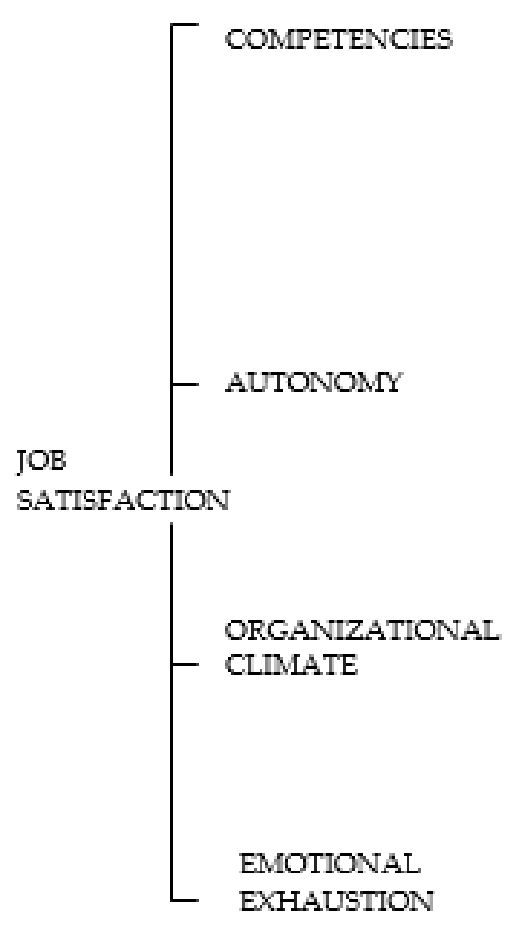

The work corresponds to their own skills and ensures their development

There are situations where the necessary skills are not available

Changing the work regime contributes to the development of additional competences

Having the ability to work alone

There is the ability to effectively manage the work schedule

Training appropriate to working conditions is provided

More complex tasks are required

There is freedom of decision in the management of one's own activity

The possibility of a flexible program is offered

There are procedures for carrying out the activity

A permanent control is exercised over the tasks and deadlines

The employer provides the necessary infrastructure to carry out the activity

The employer reimburses expenses generated by telework

There is easy communication with the team manager / coordinator, with colleagues

The coordinator gives confidence in carrying out the tasks on time

The coordinator provides support if it does not perform

Constant access to work is exhausting

There is stress about the quality and completion of tasks

There are delays in carrying out the works or corrections are requested

Conflicts arise at work due to:

- overload

- non-compliance with the requirements by the employee

- non-compliance with the requirements of some team members

- the coordinator

Additional and change requests may be exhausted

Figure 1. Areas and items in job satisfaction assessment. Source: authors' research.

Competence is the characteristic of a person or a team with the knowledge and skills necessary to perform tasks related to a particular field of professional activity [69]. Current studies treat competence as an integrative concept of knowledge, skills, and attitudes. From a legal point of view, competence represents the legitimate right of a person or a group to make decisions in a certain field of activity, at different levels [69]. Competence is a characteristic correlated with the workplace and high capabilities, but their inadequacy cannot generate satisfaction for either the owner or the employer, with a mandatory condition being their compatibility. At the same time, competence has 
a dynamic character with variability depending on self-development and permanent accumulation of information and abilities, which can oscillate compared to oneself and others. In the absence of progress, even if abilities are not lost, regression may occur compared to other employees.

Autonomy includes a sense of self-determination, the ability to resist social pressures, a way of thinking, and acting in one's own way. At the same time, autonomy is a field associated with telework through work facilities in an autonomous space, according to a flexible schedule, in which operations can be performed partially/totally according to employee's decisions. Several degrees of autonomy can be observed. At the first level is the full autonomy in which there is the freedom of the employee to develop their own rules and procedures, and to be able to carry out, according to these procedures, their own set of actions and decisions in performing tasks. At a lower level, there is a discretionary space, available to the employee, in a pre-regulated process, in which employee is able to decide on the predetermined alternatives. At the last level, even if the activity takes place in an autonomous space, the work schedule and the whole process is pre-regulated and controlled, both by specific procedures and by the obligation to concatenate the exact results with other teammates, on time and in the conditions imposed. In general, the control over the work performed is appreciated by teleworkers as a condition of quality certification and inclusion in a period of time of their activity and as a manifestation of interest and appreciation for themselves, aspects that can enhance job satisfaction.

The organizational climate consists in the technological, procedural, and relational ensemble that the company makes available to the employee in a telework regime. Reliability and quality of equipment are very important, and studies in the field indicate the paradox of connectivity that communication technologies facilitate the flow of information in terms of accuracy, speed, and security but interruptions due to networks, devices, or permissive access of teammates or coordinators may lead to stress, loss of time, and difficulty returning to work. From the point of view of procedures, with the exception of research activity or works with a high degree of creativity involving a high autonomy, for most activities, the existence of clear and precise procedures ensures increased employee comfort, and the possibility to appreciate by comparison the result of their work, in order to increase satisfaction. At the level of relationship, easy access, based on trust and help at all levels involved, ensures the effective resolution of problems that may occur and a stimulating climate of collaboration that amplifies participation and commitment to the company, as well as job satisfaction. An important role belongs to the perception that in the company there is a fair relationship between work and its remuneration, and opportunities for personal development and progress, and also for the employer.

Emotional exhaustion is an important area in evaluating job satisfaction. Isolation, prolonged working time, constant concern about job security, increased workload, and reduced opportunities to maintain positive social relationships are problems that all telework studies have reported and are also causes of stress, anxiety, and depression, with negative repercussions on the employees' mental health. Emotional exhaustion is represented on the axis of enthusiasm-depression and is felt in the case of overloading and/or depletion of emotional resources. Mental health is maintained within positive interpersonal relays, being a condition that implies the ability to adapt behavior to reality, the ability to make decisions and solve problems, the tendency for self-realization, and progress.

\section{Research Methodology}

In order to evaluate the degree of job satisfaction in the conditions of telework, we developed a semi-structured questionnaire. The first 5 items are intended to present the respondents (field of activity, age, sex, education and training, number of working days outside the employer's office). The following 42 closed items aim at expressing evaluations regarding various aspects that are aggregated by areas of interest. The default responses (very much, much, enough, little, not at all) were converted to a Likert scale from 1 to 5 , with assignment based on significance relative to job satisfaction. The representativeness of 
the questionnaire was ensured by random distribution to some entities from most economic branches, with respect to the socio-professional, age, and gender structures.

To process the answers, we performed a correlation analysis and a regression analysis using the Eviews program. A multivariate analysis of a linear regression with five work design variables was conducted. The dependent variable was job satisfaction, while the independent variables were competencies, autonomy, emotional exhaustion, and organizational climate.

The abbreviations used in the model for these variables and their evaluation are described in Table 1.

Table 1. Abbreviations of variables used to apply the correlational regressive method and their evaluation.

\begin{tabular}{ccc}
\hline Variables & Abbreviations & Items \\
\hline competencies & COMP & $6-13$ \\
autonomy & AUT & $14-17$ \\
emotional exhaustion & EE & $18-30$ \\
organizational climate & OC & $31-37$ \\
job satisfaction & JS & $38-47$ \\
\hline
\end{tabular}

\section{Empirical Findings and Discussions}

The questionnaire was distributed online in Romania. Data collection took place from February to March 2021. Prior to the COVID-19 pandemic, Romania ranked last in the EU in terms of teleworking. The COVID-19 pandemic led to the expansion of telework from $0.6 \%$ in 2019 to $24 \%$ in 2020 [70]. In this context, the Romanian interpretation was based on the observation that this phenomenon and its perception among employees is a consequence of the COVID-19 pandemic. At the same time, the crisis has affected the well-being of the population, especially as Romania is characterized by an insufficient social support infrastructure and a low standard of living compared to other EU countries (ranking in 2020 in the penultimate place in terms of GDP per capita) [71]. A total of 338 respondents completed the questionnaire, of which 228 were involved in telework in various fields of activity (consulting, accounting, audit, research, public administration, banking system, trade, agriculture, construction, education, HR, IT, tourism, etc.), with a share of $41.23 \%$ for men and $58.77 \%$ for women. From the total number of respondents, 44 respondents were up to 25 years old, 150 were between 26 and 50 years old, and 34 were over 50 years old. This research considered the possibility of applying this work regime taking into account the specificities of the activities carried out. There are many activities that require face-to-face participation of the employees involved, or the use of a specific infrastructure (equipment, premises, etc.).

The Cronbach's alpha coefficient is 0.74 , revealing a high internal consistency of the variables.

For the analyzed sample, there is a high job satisfaction (4.102) (Table 2), with half of the respondents assigning the maximum grade (5). This is explained by a high level of satisfaction in terms of work performed, collaboration with the work team and the coordinator, the position held in the organization, and the relationship between work performed and remuneration. The promotion opportunities are generally average at the level of the studied sample. The perception of job satisfaction varies between more and less, with a standard deviation of 0.619 . With respect to independent variables, the average value is around 4, higher than the average rating. Emotional exhaustion has the highest standard deviation, with the situation being normal, and the analysis aiming at aspects related to the sphere of the subjective. 
Table 2. Descriptive statistics.

\begin{tabular}{cccccc}
\hline & COMP & AUT & EE & OC & JS \\
\hline Mean & 3.969 & 3.539 & 3.765 & 3.982 & 4.102 \\
Median & 4 & 3.625 & 3.85 & 4 & 4.20 \\
Maximum & 4.75 & 4.50 & 5 & 5 & 5 \\
Minimum & 2.63 & 1.50 & 1.62 & 1.71 & 2.60 \\
Std. Dev. & 0.420 & 0.557 & 0.745 & 0.681 & 0.619 \\
\hline
\end{tabular}

The first objective of the empirical study is to determine the correlations between the selected variables. Table 3 highlights the results of the analysis.

Table 3. Covariance analysis.

\begin{tabular}{cccccc}
\hline Correlation & COMP & AUT & EE & OC & JS \\
\hline COMP & 1 & & & & \\
Probability & - & & & \\
AUT & 0.394 & 1 & & \\
Probability & 0.000 & - & 1 & \\
EE & 0.182 & 0.0758 & - & & \\
Probability & 0.006 & 0.254 & 0.315 & - & \\
OC & 0.58 & 0.451 & 0.000 & 0.634 & 1 \\
Probability & 0.000 & 0.000 & 0.215 & 0.000 & - \\
JS & 0.642 & 0.48 & 0.001 & & \\
Probability & 0.000 & 0.000 & & & \\
\hline
\end{tabular}

High values of job satisfaction are associated with high values of competencies, autonomy, emotional exhaustion, and organizational climate. From the point of view of the degree of association, we found a strong link between competencies, organizational climate, and job satisfaction. Perceived autonomy is reasonably correlated with satisfaction, a result similar to that of Pron [44]. Statistically significant correlations $(\mathrm{p}<0.05)$ are identified between all variables, except for between autonomy and emotional exhaustion. Organizational climate was configured by taking into account the requirements of decent work, identifying results similar to those obtained by Ferreira et al. and Buyukgoze-Kavas and Autin [72,73].

These correlations are presented graphically in Figure 2. The most intense correlations are those between competencies, organizational climate, and job satisfaction. On a second level of intensity are placed both the correlation between autonomy and job satisfaction and the correlation between autonomy, competencies, and organizational climate. The weakest correlations are those generated by the interaction of emotional exhaustion with both job satisfaction and other independent variables.

The results of the estimates for the regression equation obtained at the level of the entire analyzed sample are presented in Table 4.

$\mathrm{R}$-squared is $54 \%$, which indicates a high correlation between the job satisfaction and the independent variables included in the models. Competencies have a significant positive effect on job satisfaction, in accordance with the results obtained by Arifin, Madlock, Hsiao and Lin, Nikolajevaite and Sabaityte, and Ko [51-55]. At the level of the sample, an adequate combination of knowledge, skills, and attitudes, in relation to the specific tasks of the job in telework conditions, induces an improvement of job satisfaction, with an average of 4.48 , which is in the vicinity of the maximum value. Additionally, the employees included in the sample are largely able to work alone and have a high capacity to efficiently manage their work schedule. There is no demand to perform more complex tasks in the case of telework than those normally performed. The work performed generally ensures a good development of basic competencies, while the additional ones are done at an average level. There is a positive statistically significant connection between autonomy and job satisfaction, consistent with Koustelios et al. and Zurmehly [42,74]. Employees have great 
freedom in managing their activity, due to the possibility of a flexible program. At the level of employers, there are procedures that largely regulate activities, with sufficient and permanent control being exercised over the tasks and deadlines. Organizational climate has a statistically significant positive effect on job satisfaction. Employers provide the necessary infrastructure to carry out the activity. The communication with the manager/coordinator and colleagues is usually easy, with the support being provided in performing tasks if they do not perform. Employers reimburse, to a small extent, the expenses generated by telework. The results are similar to those of Castro and Martins, Singh et al., and Jain et al. [64-66]. We did not identify a statistically significant effect of emotional exhaustion on job satisfaction.

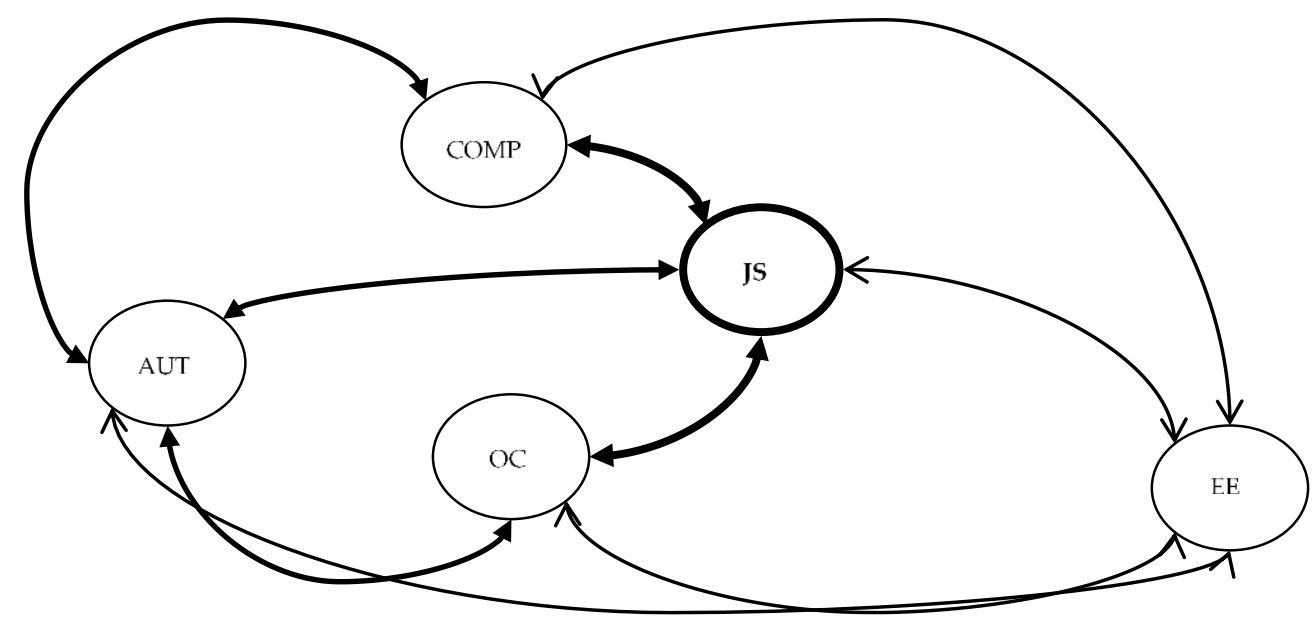

Figure 2. Graphical representation of the correlations between the variables.

Table 4. Results of the regression-model 1.

\begin{tabular}{ccccc}
\hline Variable & \multicolumn{2}{c}{ Dependent Variable: JS } & & \\
Coefficient & Std. Error & t-Statistic & Prob. \\
\hline C & -0.087634 & 0.296638 & -0.295423 & 0.7679 \\
COMP & 0.554390 & 0.083350 & 6.651347 & 0.0000 \\
AUT & 0.203203 & 0.057609 & 3.527251 & 0.0005 \\
EE & 0.025279 & 0.039848 & 0.634390 & 0.5265 \\
OC & 0.294939 & 0.055080 & 5.354739 & 0.0000 \\
R-squared & 0.541625 & & & \\
Adjusted R-squared & 0.533403 & & & \\
\hline
\end{tabular}

Note: hypothesis testing: homoskedasticity: Breusch-Pagan-Godfrey test, prob. chi-square 0.3525 ; normality of errors: Jarque-Bera test, probability of 0.2578 ; non-correlation of errors: Lagrange multiplier test, prob. chi-square 0.52; non-collinearity of variables, VIF values of independent variables less than 4: PDC 1558, AUT 1306, ED 1118, and OC 1784.

Efficient management of human resources is required to ensure job satisfaction, taking into account the needs of employees according to Maslow's pyramid [75]: physiological, safety, belonging, esteem, cognitive needs. Considering the existence of motivation for any action, managers and HR specialists must identify the profile of each employee and each individual need and establish the methods of motivation. The first level of interest is related to the salary package and job security, concerns that correspond to the first two levels of Maslow's pyramid. The following three categories of needs are based on the principles of recognition. Belonging to a group and stimulating involvement involve creating an organizational culture, by promoting certain principles and values, and a healthy organizational climate, based on the recognition of competencies and constructive collaboration. Recognition from management and colleagues, as well as self-esteem, creates a sense of trust. The ability to capitalize on own abilities and to ensure knowledge are essential elements in ensuring well-being and continuous development. It is necessary to 
establish personal and professional development plans, in accordance with the company's objectives and the held positions.

There are differences in the perception of the advantages and disadvantages of telework, depending on gender, age, education, work experience, and experience of telework in the COVID-19 pandemic [76]. The comparative analysis of job satisfaction at the level of employees grouped by various age categories reveals important aspects for human resource management (Table 5). Older generations appreciate telework much less than younger generations, who have specific skills and competencies in ICTs [76]. At the sample level, employees up to the age of 25 and those aged between 26 and 50 have a value of 4.14 for job satisfaction, while those over the age of 50 have a value of 3.91 .

Table 5. Results of the regression.

\begin{tabular}{|c|c|c|c|c|}
\hline \multicolumn{5}{|c|}{ Dependent Variable: JS, age: less than 25} \\
\hline Variable & Coefficient & Std. Error & t-Statistic & Prob. \\
\hline $\mathrm{C}$ & 0.171588 & 0.538873 & 0.318420 & 0.7519 \\
\hline COMP & 0.326550 & 0.202066 & 1.616057 & 0.1141 \\
\hline AUT & 0.231815 & 0.096050 & 2.413491 & 0.0206 \\
\hline $\mathrm{EE}$ & 0.107361 & 0.075584 & 1.420415 & 0.1634 \\
\hline OC & 0.344684 & 0.122251 & 2.819475 & 0.0075 \\
\hline R-squared & 0.709075 & & & \\
\hline Adjusted R-squared & 0.679237 & & & \\
\hline \multicolumn{5}{|c|}{ Dependent Variable: JS, age: from $26-50$} \\
\hline Variable & Coefficient & Std. Error & t-Statistic & Prob. \\
\hline $\mathrm{C}$ & -0.101204 & 0.355125 & -0.284981 & 0.7761 \\
\hline COMP & 0.653687 & 0.097511 & 6.703714 & 0.0000 \\
\hline AUT & 0.180008 & 0.073041 & 2.464462 & 0.0149 \\
\hline $\mathrm{EE}$ & -0.002722 & 0.049509 & -0.054986 & 0.9562 \\
\hline OC & 0.261647 & 0.065899 & 3.970441 & 0.0001 \\
\hline R-squared & 0.574447 & & & \\
\hline Adjusted R-squared & 0.562707 & & & \\
\hline \multicolumn{5}{|c|}{ Dependent Variable: JS, age: over 50} \\
\hline Variable & Coefficient & Std. Error & t-Statistic & Prob. \\
\hline $\mathrm{C}$ & -0.769184 & 1.202190 & -0.639819 & 0.5273 \\
\hline COMP & 0.424055 & 0.247315 & 1.714638 & 0.0971 \\
\hline AUT & 0.442144 & 0.204583 & 2.161194 & 0.0391 \\
\hline $\mathrm{EE}$ & 0.006516 & 0.119678 & 0.054447 & 0.9570 \\
\hline OC & 0.335959 & 0.179911 & 1.867366 & 0.0720 \\
\hline R-squared & 0.405389 & & & \\
\hline Adjusted R-squared & 0.323374 & & & \\
\hline
\end{tabular}

The values shown by the R-squared highlight the existence of different correlations between job satisfaction and the independent variables depending on age: $71 \%$ in the case of employees up to 25 years old, $57 \%$ in the case of those aged between 26 and 50 years, and $41 \%$ in the case of those older than 50 years. There is a statistically significant positive link between autonomy, organizational climate, and job satisfaction at the level of the whole sample. An improvement in competencies generates a greater effect on job satisfaction for employees aged between 25 and 50, who are in the growth period on the life cycle curve in terms of professional accumulation and experience. The higher value reported for employees over the age of 50 compared to that for employees up to the age of 25 is explained by the experience, enhancing the level of knowledge. The results are supported by the study conducted by Yenen [77], according to which there is a positive, moderate, and significant relationship between job satisfaction and key competencies for lifelong learning. A greater impact of autonomy on job satisfaction is observed in the case of employees over the age of 50, for whom experience ensures a certain ease in performing tasks within the required deadlines. At the level of the studied sample, there is a relatively 
similar incidence of organizational climate on employees aged up to 25 years and over 50 years (0.34) and a lower one in the case of employees aged between 25 and 50 years. The main difference is noticeable in the emotional exhaustion dimension, but the links are statistically insignificant.

Women have an average satisfaction of 4.06, lower than that of men, of 4.16 (Table 6).

Table 6. The evaluation of variables by gender.

\begin{tabular}{cccccc}
\hline Variables & COMP & AUT & EE & OC & JS \\
\hline Men & 4.07 & 3.57 & 3.91 & 4.13 & 4.16 \\
Women & 3.90 & 3.52 & 3.66 & 3.88 & 4.06 \\
\hline
\end{tabular}

Additionally, in the case of women, the evaluation of all independent variables is lower compared to that of men. Thus, in the case of men, there is a greater concordance of competencies with the work done, a greater willingness to work alone, and a superior ability to effectively manage the work schedule. At the level of the studied sample, women have more freedom in managing their own activity and are offered, to a greater extent, the possibility of a flexible program. Men perceive the existence of procedures and the exercise of permanent control over tasks and deadlines favorably, having higher average scores for job autonomy, consistent with Adler [78]. Men have a superior bargaining power, benefiting from the settlement of telecoms expenses to a greater extent.

The inclusion of the gender dimension in the analysis of job satisfaction evaluation of teleworkers determines specific configurations of the regression equations, presented in Table 7.

Table 7. Results of the regression.

\begin{tabular}{|c|c|c|c|c|}
\hline \multicolumn{5}{|c|}{ Dependent Variable: JS, males } \\
\hline Variable & Coefficient & Std. Error & t-Statistic & Prob. \\
\hline $\mathrm{C}$ & 0.987008 & 0.643715 & 1.533299 & 0.1287 \\
\hline COMP & 0.333362 & 0.158282 & 2.106123 & 0.0380 \\
\hline AUT & 0.241557 & 0.091480 & 2.640542 & 0.0098 \\
\hline $\mathrm{EE}$ & -0.132473 & 0.065794 & -2.013462 & 0.0471 \\
\hline OC & 0.356538 & 0.100562 & 3.545447 & 0.0006 \\
\hline R-squared & 0.469749 & & & \\
\hline Adjusted R-squared & 0.445918 & & & \\
\hline \multicolumn{5}{|c|}{ Dependent Variable: JS, females } \\
\hline Variable & Coefficient & Std. Error & t-Statistic & Prob. \\
\hline $\mathrm{C}$ & -0.440526 & 0.325646 & -1.352774 & 0.1785 \\
\hline COMP & 0.681365 & 0.098359 & 6.927341 & 0.0000 \\
\hline AUT & 0.137579 & 0.075705 & 1.817309 & 0.0715 \\
\hline $\mathrm{EE}$ & 0.140290 & 0.049492 & 2.834577 & 0.0053 \\
\hline OC & 0.218529 & 0.064901 & 3.367120 & 0.0010 \\
\hline R-squared & 0.633116 & & & \\
\hline Adjusted R-squared & 0.621740 & & & \\
\hline
\end{tabular}

The effects of telework on job satisfaction are perceived differently between the genders. We observed that the effects of telework in the proposed model are more significant in women, with R-squared being $63 \%$, which indicates a higher correlation between job satisfaction and the independent variables, than that of men (R-squared $47 \%$ ). There are positive statistically significant links between competencies, autonomy, organizational climate, and job satisfaction for both men and women. We note that an improvement in competencies generates a greater change in job satisfaction for women (0.68) than for men (0.33), while greater autonomy and a more favorable organizational climate have a lower impact on job satisfaction for women. The gender gap in job satisfaction grew with increasing competence, with women being much more professionally satisfied than men, 
in line with Ma and MacMillan [79]. A significant difference is determined by emotional exhaustion, the increase of which generates a decrease in job satisfaction for men and an increase for women, for which the affective side has a greater impact. Female employees are able to relieve stress from household responsibilities by adopting telework, similar to the results of Bae and Kim [3].

\section{Conclusions}

The multidimensional model for assessing job satisfaction develops the existing tools in the literature field. We consider competencies, autonomy, emotional exhaustion, and organizational climate relevant in determining job satisfaction, establishing specific items of appreciation of each field. The pertinence of the model is proved by the correlation and regression analysis performed. Processing the results of the opinion questionnaire showed a statistically significant positive link between competencies, autonomy, organizational climate, and job satisfaction. No statistically significant link was found between emotional exhaustion and job satisfaction. There are significant differences in the perception of job satisfaction between the genders and by age categories. In the case of women, the stronger correlation of competencies with job satisfaction reveals their willingness to work and to exceed the limits of traditional activities. Increasing the inclusion of women in work by expanding telework leads to improving their skills, ensuring work-specific self-efficacy, strengthening the belief that they have adequate skills to accomplish their daily jobs, all this leading to a higher degree of job satisfaction. Thus, a potential resource is capitalized, with economic and social impacts both at the micro- and macroeconomic level. Discrepancies in perception between women and men regarding the competence-job satisfaction relationship can also be explained on the basis of differences in competency assessment, with 4.07 for men, and 3.90 for women. Highly skilled employees may not perceive superior job satisfaction as they may achieve good results with relative ease, making jobs less challenging. Additionally, higher competencies are correlated with higher objectives, with their failure creating dissatisfaction. There is another significant disproportion in holding top management or better paid positions between men and women. Men experience more autonomy than women, and women usually hold positions that do not give them much autonomy. In this context, conceptual autonomy may be sensitive to gender segregation because the possibility for women to implement their own ideas is reduced, thus losing the conceptual contribution. The possibility of organizing the program is better appreciated by women, while the exercise of control and the existence of procedures are better perceived by men. Creating and maintaining an environment that offers multiple opportunities, resources, support, and useful information is appreciated more favorably by men, who will have the ability to achieve their goals and more autonomy. Telework has the advantage of evaluating the results more objectively, and more detached from the gender condition, offering women the possibility to manage both their professional and personal life depending on their own constraints. At the same time, by age group, the intensity of the correlations between the variables differs depending on the studied characteristic. The link between competencies and job satisfaction is determined by the position on the life cycle in terms of professional accumulation and experience. An essential aspect in human resource management is the correlation between autonomy and job satisfaction. Seniority linked with older age ensures a stronger correlation, due to experience and the tendency of employees to maintain a comfortable setting. The organizational climate has a relatively similar impact on job satisfaction by age categories. This can be explained by the intrinsic need of all age groups for a suitable climate. Aspects regarding the characteristics of the employees according to the age structure must be included in the personnel policy, while maintaining a balance between creativity and experience and eliminating the management problems regarding the hiring and promotion processes.

Creating decent working conditions according to SDG8, by implementing policies to support productive activities, improving resource efficiency, supporting creativity and innovation, and focusing on high added value, ensures an increase in job satisfaction. There 
is a favorable perception of the ratio between work and remuneration (3.97), with a positive impact on the productivity and growth rate of companies. Furthermore, according to SDG10, businesses have the responsibility to respect human rights, including decent working conditions. The promotion of equal opportunities and the inclusion of all, irrespective of age, are observed in the structure of respondents and in the relatively similar average value of job satisfaction (close to 4 ) at the level of the three groups considered. Increased use of telework facilitates the integration of women into the labor market, promotes the principle of gender equality, and eliminates discriminatory practices, so that those at higher risk of social exclusion have access to equal opportunities. Creating job opportunities, involvement in decision making, and creating an environment in which everyone can flourish regardless of gender can ensure an increase in the well-being of women employees. By promoting inclusive business models that empower marginalized groups, such as women, companies can have a positive impact on addressing inequality. The use of telework in a responsible manner ensures an improvement in the implementation of SDG5, SDG8, and SDG10.

The results of the study are of interest both for the academic environment, validating the results of other studies and deepening the analysis by developing a multidimensional assessment model, and for employers and HR specialists, who can use this model to substantiate the decision-making process on personnel policy towards increasing job satisfaction, as a condition for improving the performance of employees and companies.

Telework does not itself constitute a reason for job satisfaction. It triggers conditions which lead to job satisfaction. Thus, telework enhances autonomy, leads to increased competencies by enriching IT skills, makes the work schedule more flexible and harmonizes it with the psychological characteristics and family obligations of the employee, and saves of time and money, with an impact on increasing job satisfaction. At the same time, it excludes the increase in competencies through osmosis and deprives employees of sharing experiences with colleagues and socializing. In addition, telework deprives the employee of the variation offered by leaving a space that can become cloistering. These aspects negatively affect job satisfaction. The organizational climate becomes a determining factor in balancing these divergent aspects and increasing job satisfaction.

The main limitation of the research is that there is no discussion about the cultural characteristics of individuals that determine specific configurations for assessing job satisfaction. A cross-country study is needed to include different cultural patterns. Additionally, the identification of subcultures in a certain culture allows the identification of marginalized people, individuals with unique experiences, and particular characteristics. Even if our results are not atypical in terms of occupations and roles between men and women in the EU, the perception of job satisfaction cannot be generalized without taking into account certain economic, social, political, and cultural configurations.

New research should be developed through elaborated analysis, by including in the organizational climate the evaluation of the management quality and of the promoted organizational culture. Additionally, a cross-country study should be performed to include different individual cultural patterns.

Author Contributions: Conceptualization, M.A.P., M.I.S.-D., A.A.-P., S.C.C., C.M. and A.-M.P.; methodology, M.A.P., M.I.S.-D., A.A.-P., S.C.C., C.M. and A.-M.P.; investigation M.A.P., M.I.S.-D., A.A.-P., S.C.C., C.M. and A.-M.P.; writing-original draft, M.A.P., M.I.S.-D., A.A.-P., S.C.C., C.M. and A.-M.P.; writing-review and editing, M.A.P., M.I.S.-D., A.A.-P., S.C.C., C.M. and A.-M.P. All authors have read and agreed to the published version of the manuscript.

Funding: This research received no external funding.

Institutional Review Board Statement: Not applicable.

Informed Consent Statement: Not applicable.

Data Availability Statement: Not applicable.

Conflicts of Interest: The authors declare no conflict of interest. 


\section{References}

1. Eurofound. Telework in European Union. Available online: https://www.eurofound.europa.eu/publications/report/2010 / telework-in-the-european-union (accessed on 22 July 2021).

2. Cook, K.S.; Cheshire, C. Rice. Social exchange theory. Soc. Forces 2006, 68, 53-76.

3. Bae, K.B.; Kim, D. The Impact of Decoupling of Telework on Job Satisfaction in U.S. Federal Agencies. Am. Rev. Public Adm. 2016, 46, 356-371. [CrossRef]

4. Fonner, K.L.; Roloff, M.E. Why teleworkers are more satisfied with their jobs than are office-based workers: When less contact is beneficial. J. Appl. Commun. Res. 2010, 38, 336-361. [CrossRef]

5. Hashim, R.; Bakar, A.; Noh, I.; Mahyudin, H.A. Employees' Job Satisfaction and Performance through working from Home during the Pandemic Lockdown. Environ. Behav. Proc. J. 2020, 5, 461-467. [CrossRef]

6. Saltzstein, A.L.; Ting, Y.; Saltzstein, G.H. Work-family balance and job satisfaction: The impact of family-friendly policies on attitudes of federal government employees. Public Adm. Rev. 2001, 61, 452-467. [CrossRef]

7. Gajendran, R.S.; Harrison, D.A. The good, the bad, and the unknown about telecommuting: Meta-analysis of psychological mediators and individual consequences. J. Appl. Psychol. 2007, 92, 1524. [CrossRef]

8. Felstead, A.; Henseke, G. Assessing the growth of remote working and its consequences for effort, well-being and work-life balance. New Technol. Work Employ. 2017, 32, 195-212. [CrossRef]

9. Rymaniak, J.; Lis, K.; Davidavičienė, V.; Pérez-Pérez, M.; Martínez-Sánchez, Á. From Stationary to Remote: Employee Risks at Pandemic Migration of Workplaces. Sustainability 2021, 13, 7180. [CrossRef]

10. Lee, S.Y.; Hong, J.H. Does family-friendly policy matter? Testing its impact on turnover and performance. Public Adm. Rev. 2011, 71, 870-879. [CrossRef]

11. Major, D.A.; Verive, J.M.; Joice, W. Telework as a dependent care solution: Examining current practice to improve telework management strategies. Psychol. Manag. J. 2008, 11, 65-91. [CrossRef]

12. EUROSTAT. Available online: https:/ / ec.europa.eu/eurostat/web/sdi (accessed on 22 July 2021).

13. Locke, E.A. What is job satisfaction? Organ. Behav. Hum. Perform. 1969, 4, 309-336. [CrossRef]

14. Spector, P.E. Job Satisfaction: Application, Assessment, Causes, and Consequences; SAGE Publications: Thousand Oaks, CA, USA, 1977; Volume 3, p. 104.

15. Badrianto, Y.; Ekhsan, M. Effect of Work Environment and Job Satisfaction on Employee Performance in PT. Nesinak Industries. J. Bus. Manag. Account. 2020, 2, 85-91.

16. Linder-Pelz, S. Toward a theory of patient satisfaction. Soc. Sci. Med. 1982, 16, 577-582. [CrossRef]

17. Moorman, R.H. The influence of cognitive and affective based job satisfaction measures on the relationship between satisfaction and organizational citizenship behavior. Hum. Relat. 1993, 46, 759-776. [CrossRef]

18. Vroom, V.H. Work and Motivation; Wiley: Hoboken, NJ, USA, 1964.

19. Latham, G.P.; Locke, E.A. Goal setting-A motivational technique that works. Organ. Dyn. 1979, 8, 68-80. [CrossRef]

20. Adams, J.S. Inequity in Social Exchange. Adv. Exp. Soc. Psychol. 1965, 2, 267-299.

21. Judge, T.A.; Weiss, H.M.; Kammeyer-Mueller, J.D.; Hulin, C.L. Job attitudes, job satisfaction, and job affect: A century of continuity and of change. J. Appl. Psychol. 2017, 102, 356. [CrossRef] [PubMed]

22. Smith, P.C.; Kendall, L.; Hulin, C.L. The Measurement of Satisfaction in Work and Retirement: A Strategy for the Study of Attitudes; Rand McNally and Company: Chicago, IL, USA, 1969; p. 194.

23. Spector, P.E. Measurement of human service staff satisfaction: Development of the Job Satisfaction Survey. Am. J. Community Psychol. 1985, 13, 693-713. [CrossRef] [PubMed]

24. Churchill, G.A., Jr.; Ford, N.M.; Walker, O.C., Jr. Measuring the job satisfaction of industrial salesmen. J. Mark. Res. 1974, 11, 254-260. [CrossRef]

25. Johnson, G.H. An Instrument for the Measurement of Job Satisfaction 1. Pers. Psychol. 1955, 8, 27-37. [CrossRef]

26. Boxall, P.; Macky, K. Research and theory on high-performance work systems: Progressing the high-involvement stream. Hum. Resour. Manag. J. 2009, 19, 3-23. [CrossRef]

27. Fabi, B.; Lacoursière, R.; Raymond, L. Impact of high-performance work systems on job satisfaction, organizational commitment, and intention to quit in Canadian organizations. Int. J. Manpow. 2015, 36, 772-790. [CrossRef]

28. Dorta-Afonso, D.; González-de-la-Rosa, M.; García-Rodríguez, F.J.; Romero-Domínguez, L. Effects of High-Performance Work Systems (HPWS) on Hospitality Employees' Outcomes Through Their Organizational Commitment, Motivation, and Job Satisfaction. Sustainability 2021, 13, 3226. [CrossRef]

29. Chen, T.J.; Lin, C.C.; Wu, C.M. High performance work system, psychological efficacy, job satisfaction and task performance in the Hotel Workplace. Open J. Soc. Sci. 2016, 4, 76-81. [CrossRef]

30. Bashir, M.; Jianqiao, L.; Zhao, J.; Ghazanfar, F.; Khan, M.M. The role of demographic factors in the relationship between high performance work system and job satisfaction: A multidimensional approach. Int. J. Bus. Soc. Sci. 2011, 2, 18.

31. Ming, G.; Ganli, L.; Fulei, C. High-Performance Work Systems, Organizational Identification and Job Satisfaction: Evidence from China. Pak. J. Stat. 2014, 30, 751-766.

32. Stiles, J.; Smart, M.J. Working at home and elsewhere: Daily work location, telework, and travel among United States knowledge workers. Transportation 2020, 1-31. [CrossRef] 
33. Hamer, R.; Kroes, E.; Van Ooststroom, H. Teleworking in the Netherlands: An evaluation of changes in travel behaviour. Transportation 1991, 18, 365-382. [CrossRef]

34. Elliott, D.; Swartz, E.; Herbane, B. Business Continuity Management: A Crisis Management Approach, 2nd ed.; Routledge: New York, NY, USA, 2010.

35. Hillmann, J.; Guenther, E. Organizational resilience: A valuable construct for management research? Int. J. Manag. Rev. 2021, 23, 7-44. [CrossRef]

36. Karácsony, P. Impact of teleworking on job satisfaction among Slovakian employees in the era of COVID-19. Probl. Perspect. Manag. 2021, 19, 1-9. [CrossRef]

37. Belzunegui-Eraso, A.; Erro-Garcés, A. Teleworking in the Context of the Covid-19 Crisis. Sustainability 2020, 12, 3662. [CrossRef]

38. Ordóñez Parada, A.I. Factors that influence job satisfaction of teleworkers: Evidence from Mexico. Glob. J. Bus. Res. 2018, 12, 41-49.

39. Brunelle, E.; Fortin, J.A. Distance Makes the Heart Grow Fonder: An Examination of Teleworkers' and Office Workers' Job Satisfaction through the Lens of Self-Determination Theory. SAGE Open 2021, 11, 2158244020985516. [CrossRef]

40. Suh, A.; Lee, J. Understanding teleworkers' technostress and its influence on job satisfaction. Internet Res. 2017, 27, 140-159. [CrossRef]

41. Finn, C.P. Autonomy: An Important Component for Nurses' Job Satisfaction. Int. J. Nurs. Stud. 2001, 38, 349-357. [CrossRef]

42. Koustelios, A.D.; Karabatzaki, D.; Kousteliou, I. Autonomy and Job Satisfaction for a Sample of Greek Teachers. Psychol. Rep. 2004, 95, 883-886. [CrossRef] [PubMed]

43. Lange, T. Job satisfaction and self-employment: Autonomy or personality? Small Bus. Econ. 2012, 38, 165-177. [CrossRef]

44. Pron, A.L. Job satisfaction and perceived autonomy for nurse practitioners working in nurse-managed health centers. J. Am. Acad. Nurse Pract. 2013, 25, 213-221. [CrossRef]

45. Zangaro, G.A.; Soeken, K.L. A Meta-Analysis of Studies of Nurses' Job Satisfaction. Res. Nurs. Health 2007, 30, 445-458. [CrossRef] [PubMed]

46. Skaalvik, E.M.; Skaalvik, S. Teacher self-efficacy and perceived autonomy: Relations with teacher engagement, job satisfaction, and emotional exhaustion. Psychol. Rep. 2014, 114, 68-77. [CrossRef]

47. Chung-Yan, G.A. The Nonlinear Effects of Job Complexity and Autonomy on Job Satisfaction, Turnover and Psychological Well-Being. J. Occup. Health Psychol. 2010, 15, 237-251. [CrossRef]

48. Keenan, J. A concept analysis of autonomy. J. Adv. Nurs. 1999, 29, 556-562. [CrossRef]

49. Peng, Y.P. The relationship between job satisfaction, job autonomy and job performance in university librarians. J. Educ. Media Libr. Sci. 2012, 49, 597-608.

50. Baert, S.; Lippens, L.; Moens, E.; Weytjens, J.; Sterkens, P. The Covid-19 Crisis and Telework: A Research Survey on Experiences, Expectations and Hopes; IZA Institute of Labor Economics: Bonn, Germany, 2020; pp. 1-37.

51. Arifin, H.M. The Influence of Competence, Motivation and Organisational Culture to High School Teacher Job Satisfaction and Performance. Int. Educ. Stud. 2015, 8, 35-48. [CrossRef]

52. Madlock, P.E. The Link between Leadership Style, Communicator Competence, and Employee Satisfaction. J. Bus. Commun. 2008, 45, 61-78. [CrossRef]

53. Hsiao, J.M.; Lin, D.S. The impacts of working conditions and employee competences of fresh graduates on job expertise, salary and job satisfaction. J. Rev. Glob. Econ. 2018, 7, 246-259. [CrossRef]

54. Nikolajevaite, M.; Sabaityte, E. Relationship between employees' competencies and job satisfaction: British and Lithuanian employees. Psychol. Res. 2016, 6, 684-692. [CrossRef]

55. Ko, W.H. The relationships among professional competence, job satisfaction and career development confidence for chefs in Taiwan. Int. J. Hosp. Manag. 2012, 31, 1004-1011. [CrossRef]

56. Trivellas, P.; Akrivouli, Z.; Tsifora, E.; Tsoutsa, P. The impact of knowledge sharing culture on job satisfaction in accounting firms. The mediating effect of general competencies. Procedia Econ. Financ. 2015, 19, 238-247. [CrossRef]

57. Kowal, J.; Roztocki, N. Job satisfaction of IT professionals in Poland: Does business competence matter? J. Bus. Econ. Manag. 2015, 16, 995-1012. [CrossRef]

58. Skaalvik, E.M.; Skaalvik, S. Teacher job satisfaction and motivation to leave the teaching profession: Relations with school context, feeling of belonging, and emotional exhaustion. Teach. Teach. Educ. 2011, 27, 1029-1038. [CrossRef]

59. Lewig, K.A.; Dollard, M.F. Emotional dissonance, emotional exhaustion and job satisfaction in call centre workers. Eur. J. Work. Organ. Psychol. 2003, 12, 366-392. [CrossRef]

60. Moon, T.W.; Hur, W.M. Emotional Intelligence, Emotional Exhaustion and Job Performance. Soc. Behav. Personal. Int. J. 2011, 39, 1087-1096. [CrossRef]

61. Karatepe, O.M.; Tekinkus, M. The Effects of Work-Family Conflict, Emotional Exhaustion and Intrinsic Motivation on Job Outcomes of Front-Line Employees. Int. J. Bank Mark. 2006, 24, 173-193. [CrossRef]

62. Sonnentag, S.; Mojza, E.J.; Binnewies, C.; Scholl, A. Being engaged at work and detached at home: A week-level study on work engagement, psychological detachment, and affect. Work Stress 2008, 22, 257-276. [CrossRef]

63. Troesch, L.M.; Bauer, C.E. Second career teachers: Job satisfaction, job stress, and the role of self-efficacy. Teach. Teach. Educ. 2017, 67, 389-398. [CrossRef] 
64. Castro, M.; Martins, N. The Relationship between Organisational Climate and Employee Satisfaction in a South African Information and Technology Organisation. SA J. Ind. Psychol. 2010, 36, 1-9. [CrossRef]

65. Singh, R.R.; Chauhan, A.; Agrawal, S.; Kapoor, S. Impact of organisational climate on job satisfaction-A comparative study. Int. J. Comput. Sci. Manag. Stud. 2011, 11, 2231-5268.

66. Jain, K.K.; Jabeen, F.; Mishra, V.; Gupta, N. Job Satisfaction as Related to Organisational Climate and Occupational Stress: A Case Study of Indian Oil. Int. Rev. Bus. Res. Pap. 2007, 3, 193-208.

67. De Simone, S.; Planta, A.; Cicotto, G. The role of job satisfaction, work engagement, self-efficacy and agentic capacities on nurses' turnover intention and patient satisfaction. Appl. Nurs. Res. 2018, 39, 130-140. [CrossRef]

68. Ćulibrk, J.; Delić, M.; Mitrović, S.; Ćulibrk, D. Job satisfaction, organizational commitment and job involvement: The mediating role of job involvement. Front. Psychol. 2018, 9, 132. [CrossRef] [PubMed]

69. Zamfir, C.; Vlăsceanu, L. Dictionar de Sociologie; Editura Babel: Bucuresti, Romania, 1993.

70. Eurofound. Telework-The Silent Revolution Taking Place in the EU. Spectacular Growth in Romania. Available online: https:// cursdeguvernare.ro/eurofound-telemunca-revolutia-tacuta-ce-se-desfasoara-in-ue-crestere-spectaculoasa-si-in-romania.html (accessed on 22 July 2021).

71. EUROSTAT. Available online: https:/ / ec.europa.eu/eurostat/databrowser/view/sdg_08_10/default/table?lang=en (accessed on 22 July 2021).

72. Ferreira, J.A.; Haase, R.F.; Santos, E.R.; Rabaça, J.A.; Figueiredo, L.; Hemami, H.G.; Almeida, L.M. Decent work in Portugal: Context, conceptualization, and assessment. J. Vocat. Behav. 2019, 112, 77-91. [CrossRef]

73. Buyukgoze-Kavas, A.; Autin, K.L. Decent work in Turkey: Context, conceptualization, and assessment. J. Vocat. Behav. 2019, 112, 64-76. [CrossRef]

74. Zurmehly, J. The relationship of educational preparation, autonomy, and critical thinking to nursing job satisfaction. J. Contin. Educ. Nurs. 2008, 39, 453-460. [CrossRef] [PubMed]

75. McLeod, S. Maslow's hierarchy of needs. Simply Psychol. 2007, 1, 1-18.

76. Raišienè, A.G.; Rapuano, V.; Varkulevičiūtè, K.; Stachová, K. Working from home-Who is happy? A survey of Lithuania's employees during the COVID-19 quarantine period. Sustainability 2020, 12, 5332. [CrossRef]

77. Yenen, E.T. An Examination of Relationship between English Teachers' job Satisfaction and Key Competences for Lifelong Learning. Mojes Malays. Online J. Educ. Sci. 2018, 7, 35-46.

78. Adler, M.A. Gender Differences in Job Autonomy: The Consequences of Occupational Segregation and Authority Position. Sociol. Q. 1993, 34, 449-465. [CrossRef]

79. Ma, X.; MacMillan, R.B. Influences of Workplace Conditions on Teachers' Job Satisfaction. J. Educ. Res. 1999, 93, 39-47. [CrossRef] 